\title{
Synthesis of Copper-Chitosan Nanocomposites and their Applications in Treatment of Local Pathogenic Isolates Bacteria
}

\section{SOHIER M.SYAME ${ }^{\star 1,2}$, W.S.MOHAMED ${ }^{3}$, REHAB K. MAHMOUD ${ }^{4}$ and SHIMAA T. OMARA ${ }^{1}$}

\author{
'Department of Microbiology and Immunology, National Research Centre, \\ 33 Bohouth St. Dokki, Postal Code 12311, Giza, Egypt. \\ 2Department of Polymer, National Research Centre, 33 Bohouth St. Dokki, \\ Postal Code 12311, Giza, Egypt. \\ ${ }^{3}$ Department of Chemistry, Faculty of Science, Beni-Suif University, Egypt. \\ ${ }^{4}$ Department of Chemistry, Faculty of Science, Beni-Suif University, Egypt. \\ ${ }^{*}$ Corresponding author E-mail: sohiersyame@yahoo.com
}

http://dx.doi.org/10.13005/ojc/330632

(Received: May 23, 2017; Accepted: July 01, 2017)

\begin{abstract}
Development of nanotechnology, nanoparticles based product and its application is generating interest of many researchers due to its promising biological achievement. However, it is well known that inorganic nanomaterials are good antimicrobial agents. Among the various nanoparticles, metal nanoparticles as copper assume special importance due to its low cost and easy availability. In this study, the green synthesis method as eco-friendly approach is used to produce biologically copper oxide nanoparticles from Ficus carica leaf extract, stable CuO NPs were formed. The synthesized nanoparticles is characterized through the UV-Vis Spectrophotometer as it found to be $437 \mathrm{~nm}$, Transmission Electron microscopy (TEM) investigated particle sizes in the range 51-62 nm and typical XRD patterns of the formed CuO NPs with high phase purity were obtained. Chitosan stabilizer as naturally occurring polymers was added to the prepared copper nanoparticles in different amounts to obtain Chitosan-CuO with different $\mathrm{CuO}$ percentage for long-term stability, for prevention the agglomeration of nanoparticles and enhancing their antibacterial efficacy. FTIR spectroscopy analysis was performed to copperoxide nanoparticle, chitosan, copperoxide chitosan composite to confirm that $\mathrm{CuO}$ nanoparticle was mixed with polymer. The antibacterial efficacy of chitosan, copper nanoparticles alone was studied against 22 bacterial pathogen like Coaggulase +ve S. aureus, methicillin-resistant Coaggulase -ve S. aureus, Klebsiella pneumonia as gram positive bacteria, Escherichia coli, e.coli 0157 Salmonella typhi, Pseudomonas aeruginosa as gram negative bacteria that showed antibacterial activity against Gram positive as well as Gram negative bacteria. Antimicrobial activities of polymer/metal composites (Co oxide-chitosan nanoparticle) is studied against the same bacterial pathogen. The effect of the prepared Chitosan$\mathrm{CuO}$ composite on ultrastructure of bacterial cells were evaluated by scanning electron microscopy (SEM), it was found that the antibacterial activity of Cu-chitosan nanoparticle composite is more greater than antibacterial activity of copper nanoparticles and chitosan alone that indicate the addition of chitosan stabilizer enhance at great extent the antimicrobial activity of CuO NPs.
\end{abstract}

Keywords: Copper oxide nanoparticle, Copper oxide -Chitosan nano particle composite, Ficus Carica leaf extract, Anti-microbial activity. 


\section{INTRODUCTION}

Resistance of microorganisms to antibiotics have been increased, so many attempts have been demonstrated for synthesis of resistant antimicrobial compounds against many pathogenic microorganisms which cause dangerous threat to health ${ }^{1}$. Nanotechnology is an important research field concerning with the manipulation and design of small particles, in the range of $100 \mathrm{~nm}$ or less called nano particles $^{2-4}$ that showed a wide range of properties which differ from its bulk material as electrical, optical, magnetic, catalytic and biological activity as they exhibit a wide range of anti-microbial activity against different species of Gram-negative, Grampositive bacteria and fungi ${ }^{5-7}$. Metal nano particles (NPs) as (NiO, $\mathrm{CuO}, \mathrm{Sb}_{2} \mathrm{O}_{3}$ and $\mathrm{ZnO}$,) have been subjected of research interest in the last few years especially CuO NPs which gained great attention of researchers due to its potential industrial uses as catalytic process, gas sensors, solar cells and super conductors $^{1,8}$, also its application in wound dressings and biocidal properties ${ }^{9-11}$. Its well-known that copper is greatly toxic to microorganisms such as bacteria (Pseudomonas aeruginosa, Staphylococcus aureus, E.coli ,) to be considered an effective bactericidal can be used in water treatment and food packages ${ }^{12}$. The synthesis of stable uniformly-shaped CuO NPs has showed great difficulty due to presence of some toxic chemicals formed by Chemical synthesis methods absorbed on the surface to cause harmful effects in medical applications. The development of eco-friendly methods for the preperation of these nano materials as new inexpensive acceptable methodology of low cost production and less time required have been considered from the most important aspects today, scientists used plant extracts for greens ynthesis of different nanoparticles such as Euphorbia tirucalli $i^{13}$, neem ${ }^{14}$, Cinnamomum camphora $^{15}$, Emblica officinalis ${ }^{16}$, tamarind ${ }^{17}$, lemon grass $^{18}$ and alfalfa ${ }^{19,20}$. Polymer nanocomposites which consists of metal nanostructures and polymers are of special prac-tical interest today. The communication of biology with nanotechnology gives the chance for the development of nanoscale materials can be used in several applications at biological science and clinical medicine 21,22 . The postsynthesis stability of metal nanoparticles in relation to its shape and size is very crucial as nanoparticles of weakly aggregation or dispersed in suspension different from those of strongly aggregated nano particles at their reactivity and its rates of surface reactions ${ }^{23,24}$, so the immobilization of colloidal metal nano particles with naturally occurring polymers is very important for prevention the aggregation and create a great positional stability to the nano particles to be used in a wide range of application, as well as such alternation in chemicophysical properties may enhance minimum bactericidal concentration $(\mathrm{MBC})$ /minimum inhibitory concen-tration (MIC), antibacterial activity values ${ }^{25}$. Chitosan is the second naturally occurring biopolymer, it is composed of $\mathrm{N}$-acetylglucosamine and glucosamine units, it is a nontoxic bio-degradable and biocompatible polymer have many applications in the biomedical and pharmaceutical fields ${ }^{26}$. It is recorded that chitosan of lower molecular weight has been showed strong bacterial and superior biological activities than high molecular weight. It has been recorded that chitosan act as antibacterial and anti-fungal substance ${ }^{27}$. As chitosan disrupting the cell membrane by binding to the bacterial cell surface of the negative charge, changing its permeability that leading to come out of material inside the bacterial cells causes its death ${ }^{28}$. Chitosan has antibacterial activity only in an acidic medium as its not soluble above $\mathrm{pH}$ 6.5. There are many factors affect the antibacterial activity of chitosan as degree of polymerization, $\mathrm{pH}$ of the solution and chitin type ${ }^{27}$. Chitosan exhibits greater antibacterial activity against Gram-positive than Gram-negative bacteria, as cell wall in Gram-positive bacterium, is composed of one layer of peptide polyglycogen with large numbers of pores that allow foreign materials to enter into the cell easily in contrast to gram-negative bacterium of peptide polyglycogen thin cell wall membrane and bilayer outer membrane from of lipopolysaccharide, phospholipids and lipoprotein, that act as a barrier against foreign materials ${ }^{29,30,31}$. In this paper, $\mathrm{CuO}$ NPs were prepared from plant extract of Ficus carica. The obtained product was charac-terized with the aid of PXRD, UV-visible, and TEM. Further, chitosan was prepared and added by different concentration to the synthesized nanoparticles to produce copperoxide chitosan nanocomposite finally CuO Nps, chitosan and copperoxide chitosan nanocomposite was evaluated for antibacterial activities by employing, Coaggulase +ve $S$. aureus, methicillin-resistant Coaggulase -ve S. aureus as Gram positive bacteria, Escherichia coli 0157, Pseudomonas aeruginosa, Salmonella typhi and Klebsiella pneumonia as Gram negative bacteria using agar disc diffusion method 


\section{MATERIAL AND METHODS}

\section{Preparation of plant leaf extract}

The powder of Ficus carica was purchased, weighed $5 \mathrm{~g}$ and dissolved in $100 \mathrm{~mL}$ of distilled water and boiled for $20 \mathrm{~min}$. at $50^{\circ} \mathrm{C}$. The extract is filtered by Whatmann No1 filter Paper before centrifuging at $1200 \mathrm{rpm}$ for $2 \mathrm{~min}$. to remove biomaterials.Then the filtrate is stored in a tight seal pack under $4{ }^{\circ} \mathrm{C}$ for further use.

\section{Synthesis of copper oxide (CuO) nanoparticles using Ficus carica extracts}

$20 \mathrm{~mL}$ solution of Ficus carica extract was introduced drop wise into $80 \mathrm{~mL}$ of $1 \mathrm{mM}(1 \mathrm{mM})$ solution of copper sulphate $\left(\mathrm{CuSO}_{4} \cdot 5 \mathrm{H}_{2} \mathrm{O}\right)$ in a 250 $\mathrm{ml}$ Erlenmeyer flask under continuous stirring. After the complete addition of extract, the flask was then kept stirring for overnight at room temperature. Within a particular time, the colour solution was changed into straw yellow, which indicates the formation of copper oxide nanoparticles as seen in Fig.(1). CuO nano particles solution was purified by repeated centrifugation at $12,000 \mathrm{rpm}$ for $15 \mathrm{~min}$. followed by re-dispersion of the pellet in deionized water to remove any unwanted biological materials. Then the $\mathrm{CuO}$ nano particles were dried in oven at $80^{\circ} \mathrm{C}$. The obtained products of $\mathrm{CuO}$ nano particles were stored in air tight container for further analysis.

\section{Characterization of copper oxide nanoparticles}

The synthesized copper Nanoparticles were characterized through UV-Vis spectrophotometer HITACHI U2300. The reduction of copper Nanoparticles was Monitored by UVspectrophotometer range of absorbance from 250$480 \mathrm{~nm}$. The Morphology and mean particle size of Copper oxide nanoparticles synthesized by this green method were determined by transmission electronic microscopy( SEM) and (TEM). The SEM analysis was established by using Supra Zeiss with $1 \mathrm{~nm}$ resolution at $30 \mathrm{kV}$ with $20 \mathrm{~mm}$ Oxford EDS detector. The elemental composition in the reaction mixture was determined by EDX analysis, where the TEM images were obtained by (JEM-1230-electron microscopy operated at $60 \mathrm{KV}$ ). Before taking a TEM image the sample was diluted at least 10 times by water. A drop of well dispersed diluted sample was placed onto a copper grid (200 mesh and covered with a carbon membrane) and dried at ambient temperature. A drop of phosphotungestic acid $(0.4 \%)$ as a stain was deposited over the dried sample.
The crystal structure was characterized by X-ray diffractometer, (XRD-6000, Shimadzu) equipped with CuK $\alpha$ radiation source $(\lambda=0.154056 \mathrm{~nm})$ using $\mathrm{Ni}$ as filter at a setting of $30 \mathrm{kV} / 30 \mathrm{~mA}$. All XRD data were collected under the experimental conditions in the angular range $3^{\circ} \leq 2 \theta \leq 80^{\circ}$. FT-IR analysis is used to identify and get an approximate ides of the possible biomolecules that are responsible for capping and stabilization of the CuO-NPs with the Ficus carica leaf extract.

\section{Preparation of chitosan-CuO nanocomposite:}

Different amounts of the prepared $\mathrm{CuO}$ were sonicated in chitosan solution for $20 \mathrm{~min}$. and then stirred at room temperature for $8 \mathrm{~h}$ and washed with ultra pure water by ultracentrifugation to remove unbound Chitosan, then collected and dried at room temperature to obtain Chitosan-CuO with different CuO percentage.

Characterization of the formed nano composite by fourier transforms infra red spectroscopy

FTIR spectra chitosan nanocomposites were recorded on a FTIR spectrophotometer (Thermo Nicolet, NEXUS, TM) in the range of $4000-400 \mathrm{~cm}^{-1}$ using $\mathrm{KBr}$ pellets.

\section{Evaluation of antibacterial activity In Vitro materials}

Twenty two bacterial strains from microbiology and immunology department, National Research Center, Cairo, Egypt were isolated. They include Coaggulase +ve S. aureus, methicillinresistant Coaggulase -ve S. aureusas Gram-positive bacteria and Escherichia coli, E.coli 0157, Klebsiella pneumoniae, Salmonella typhi, Pseudomonas aeruginosa, etc as Gram-negative bacteria. The most frequent and abundant bacteria in many disease infection represent Gram positive and Gram negative bacteria, respectively were selected. Fresh inoculants for antibacterial assessment were prepared on nutrient broth at $37^{\circ} \mathrm{C}$ for 24 hours.

\section{Test method}

The antibacterial spectrum of copper oxide nanoparticles, chitosan, Cu-chitosan nanoparticle composite samples were determined against the test bacteria by disc well - diffusion method on an agar plate ${ }^{28}$. Briefly incubated cultures of bacteria were swabbed uniformly on the individual plates using sterile cotton swabs on the Muller Hinton Agar, 50 $\mu \mathrm{l}$ of copper oxide nanoparticles, chitosan and $\mathrm{Cu}$ - 
chitosan nanoparticle composite samples with different concentration of 1,2,3,5\%were loaded in sterile discs, Plates were incubated at $37^{\circ} \mathrm{C}$ for 24 hours. The inhibition effect was verified by the presence of inhibition zones around the discs where the solution was deposited and sized for analysis and comparison.

\section{Morphological analysis by scanning electron microscope}

Bacterial cultures of E. coliO157:H7, E.coli 0157:H7, methicillin-resistant Coaggulase -ve $S$. aureus were reated with $2 \mathrm{mg} / \mathrm{ml}$ copper oxide nano particles for 8 hours. Aliquots of $1 \mathrm{~mL}$ samples were centrifuged for $2 \mathrm{~min}$. at $4000 \mathrm{rpm}$ and the cell pellets were resuspended in $0.1 \mathrm{~mL} \mathrm{MH}$ broth. Subsequently, $20 \mu \mathrm{l}$ of each concentrated sample was deposited and spread onto a glass coverslip pre-washed with acetone and ethanol. After drying the slips for $15 \mathrm{~min}$. at $37^{\circ} \mathrm{C}$, the bacterial cells were subjected to fixation, dehydration, and critical point drying for SEM analysis as described previously ${ }^{32}$.

\section{RESULTS}

\section{Synthesis of copper oxide nanoparticles (visual inspection)}

After $28 \mathrm{~h}$ of reaction, The reaction mixture colour change from Light to dark colour, that can be given by below (Fig.1) the reduction of $\mathrm{Cu}^{+}$ions it show the dark brown colour as the Surface Plasmon vibration was the excited in a metal nano particles.

\section{Characterization of copper oxide nanoparticles UV-spectrophotometer}

The reduction of $\mathrm{Cu}+$ ions was monitored by UV-Vis Spectrophotometer at range( 250-500) for the metal ions stability. The peak was obtained at $437 \mathrm{~nm}$ as showed in Figure. 2.

\section{Scanning electron microscope (SEM) analysis}

SEM images revealed that the synthesized copper oxide nanoparticles are clustered and the surfaces of the aggregates are rough. The SEM images indicated that the size of crystalline $\mathrm{CuO}$ nanoparticles particles from the SEM scale are ranged between 51 to $62 \mathrm{~nm}$ Figure.3.

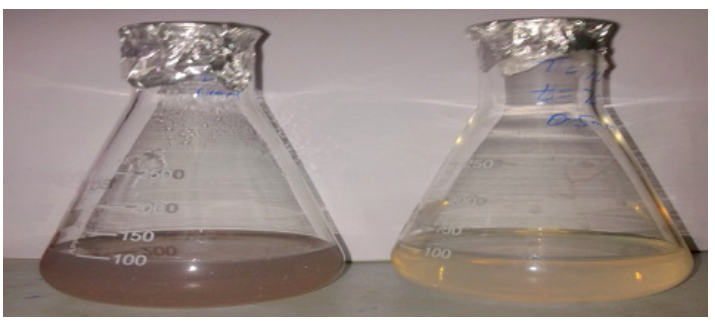

Fig.1. Formation Copper oxide nanoparticle

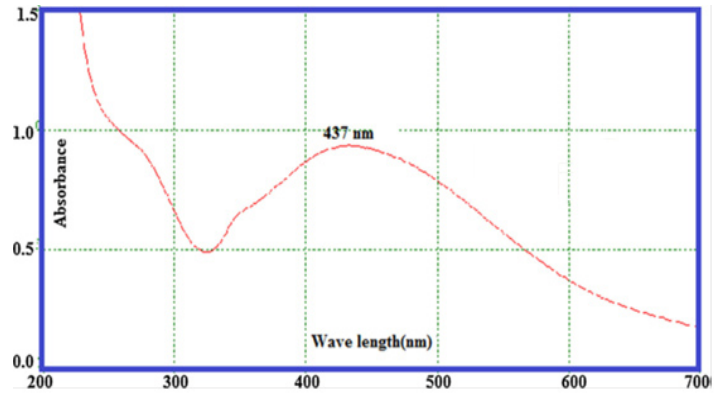

Fig.2. UV-Vis absorption spectra of Copper oxide nanoparticle materials synthesized with $(1 \mathrm{mM})$ solution of copper sulphate(CuSO4.5H2O) and Ficus carica extracts

\section{TEM analysis of CuO nano particles}

The shape and size of the synthesized CuO-NPs were analysed by TEM analysis .Fig. 4 shows the TEM image of biosynthesized CuONPs. The synthesized CuO-NPs have particle size in nano range with spherical shape.

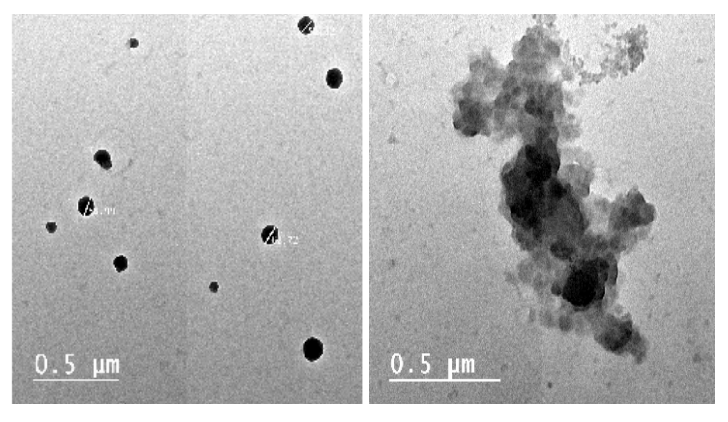

Fig.3. SEM image of the synthesized CuO nanoparticles

As seen in Fig. 5 shows the X-ray diffraction (XRD) pattern of the CuO powder synthesized from of copper sulphate(CuSO4.5H2O) in the presence of Ficus carica extracts. The XRD pattern revealed the orientation and crystalline nature of copper oxide nano particles. The peak are indexed at (110), (-111), (111), (-202), (020), (202), (-113), (-311), (220), (311), and (004) planes with position with $2 \theta$ values of $32.48^{\circ}, 35.48^{\circ}, 38.95^{\circ}, 48.74^{\circ}$, $53.44^{\circ}, 58.33^{\circ}, 61.53^{\circ}, 65.78^{\circ}, 66.24^{\circ}, 72.42^{\circ}$ and $75.04^{\circ}$. No another diffraction peaks of other phases are detected, investigating the phase purity of CuO-NPs. The average crystallite size of the synthesized copper oxide nanoparticles was calculated to be $14 \mathrm{~nm}$ using Debye-Scherrer equation (Klug and Alexander, 1954): $D=K \lambda / \beta \cos \theta$. Where $D$ is the crystallite size of copper oxide nanoparticles, $\lambda$ represents wavelength of $x$-ray source $0.1541 \mathrm{~nm}$ ) used in XRD, $\beta$ is the full width at half maximum of the diffraction peak, $\mathrm{K}$ is the Scherrer constant with value from 0.9 to 1 and $\theta$ is the Bragg angle. 


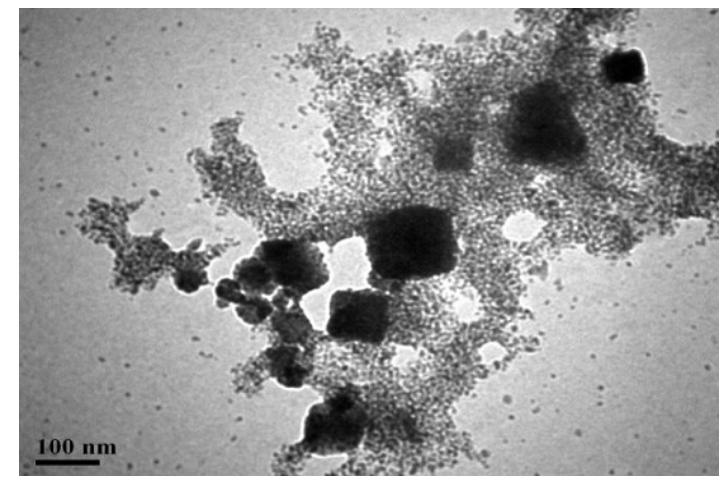

Fig.4. TEM image of the synthesized CuO nanoparticles X-ray diffraction Analysis

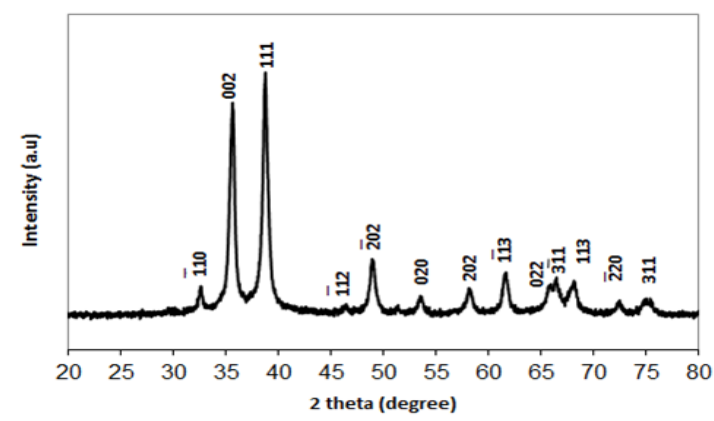

Fig.5. XRD pattern of the synthesized copper oxide nano particles Fourier transform infrared spectroscopy analysis

Fourier Transform Infrared (FTIR) spectra of $\mathrm{CuO}$ nano particles, Chitosan and chitosan-CuO composite samples are shown in Fig. 6 from it is clear that. A sharp peak at $3388 \mathrm{~cm}^{-1}$ can be indicated to hydrogen bonded $\mathrm{O}-\mathrm{H}$ groups of alcohols and phenols and also to the presence of amines $\mathrm{N}-\mathrm{H}$ of amide ,The major peak was observed to be 513 $\mathrm{cm}^{-1}$ should be a stretching of $\mathrm{Cu}-\mathrm{O}$, While the bands at $1465 \mathrm{~cm}^{-1}$ and the peak at $1319 \mathrm{~cm}^{-1}, 1346 \mathrm{~cm}^{-1}$ assigned to $\mathrm{C}=\mathrm{O}$ stretching and $\mathrm{N}-\mathrm{H}$ bending. While FTIR of chitosan was showed that the intense and wide band at $3220 \mathrm{~cm}^{-1}$ is attributed to the vibration of $-\mathrm{OH}$ group, the characteristic peaks at $1513 \mathrm{~cm}^{-1}$ and $1040 \mathrm{~cm}^{-1}$ are due to the vibration of $\mathrm{C}=\mathrm{O}$. In chitosan-CuO composite spectra, the intense bands at $3480 \mathrm{~cm}^{-1}$ and $1040 \mathrm{~cm}^{-1}$ are attributed to the stretching vibration of $\mathrm{N}-\mathrm{H}$ and $\mathrm{Cu}-\mathrm{O}$ respectively.

\section{Activity of copper oxide nanoparticles}

Antimicrobial efficacy of CuO-NPs was analyzed against 22 pathogenic bacterial isolates represented grame negative, gram positive bacteria as E.coli 0157, Pseudomonas aeruginosa, Salmonella typhimurium, Klebsiella pneumoniae subsp. Ozaenae, Aeromonas, coaggulase +ve Staphylococcu saureus and methicillin-resistant
Coaggulase -ve Staphylococcu saureus. Table. (1) represents the antibacterial activity of CuO NPs for various bacteria by the disc diffusion assay. Results showed that CuO NPs demonstrated excellent antimicrobial activity against wide range of bacteria also $\mathrm{CuO}$ nanoparticles showed significant antibacterial activity on Gram negative bacterial strains than Gram positive one. According to zone of inhibition copper nano particles strongly inhibited the growth of Gram negative bacteria as the zone of inhibition recorded for E.coli 0157 (6.6 mm), Pseudomonas aeruginosa $(6.3 \mathrm{~mm})$, Salmonella typhimurium, Klebsiella pneumoniae subsp. Ozaenae $(6.1 \mathrm{~mm})$, Aeromonas $(6 \mathrm{~mm})$. On the other hand these nano particles showed a low inhibitory effect on the growth of Coaggulase +ve Staphylococcu saureus $(3.1 \mathrm{~mm})$ and methicillin-resistant Coaggulase -ve Staphylococcu saureus (3.7 mm).

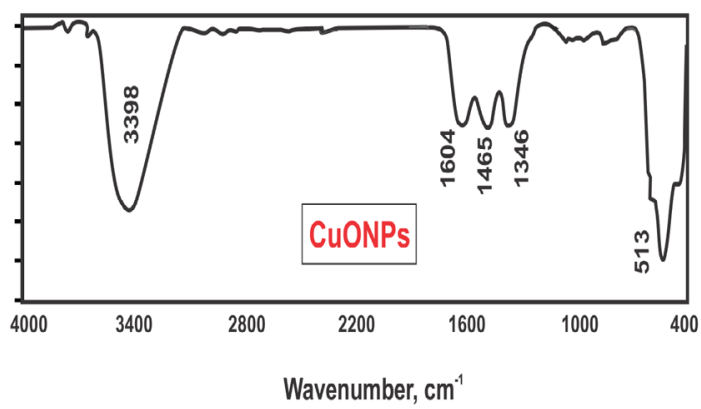

(a)

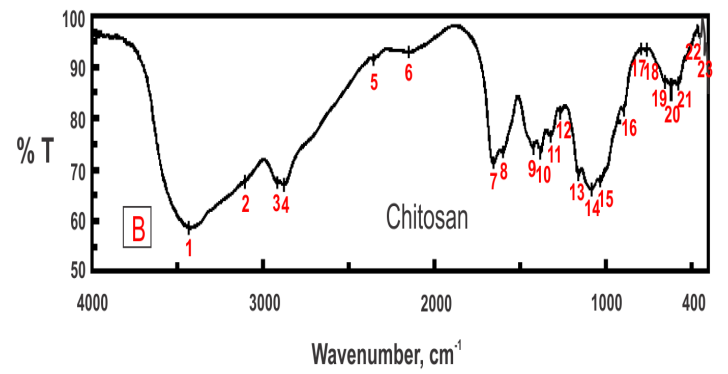

(b)

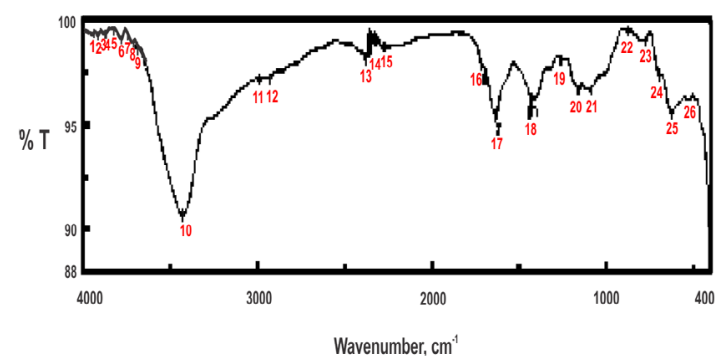

(c)

Fig. 6. FT-IR of synthesized (A) CuO-NPs, (B) Chitosan and (C) chitosan-CuO composite samples. in Ficus, leaf extract 
The result of antibacterial activity of chitosan

Chitosan was showed antibacterial activity against gram negative, gram positive microor-ganisms as shown in table.2, the zone of inhibition of the chitosan vary from 2 to $3.9 \mathrm{~mm}$ depending on the strain of the bacteria as it showed the maximum values against Gram positive microorganism as Coaggulase +ve Staphylococcu saureus $3.6 \mathrm{~mm}$ and $3.9 \mathrm{~mm}$ for methicillin-resistant Coaggulase -ve Staphylococcu saureus where diameter of zone of inhibition of the gram negative microorganisms was ranged from $2 \mathrm{~mm}$ for Shigella sonnei to $2.9 \mathrm{~mm}$ for E.coli O157.

\section{Antibacterial activity of chitosan with CuO nanoparticles ( $\mathrm{mm}$.)}

The antibacterial activity of the $\mathrm{CuO}$ nanoparticles with chitosan were evaluated against 2 Gram positive and twenty Gram negative bacterial

Table. 1: Antibacterial activity of copper oxide nanoparticles

\begin{tabular}{lc}
\hline No. Bacteria & $(\mathrm{mm})$ \\
& $\mathrm{CuO}$ \\
nanoparticles & $\%$ \\
\hline
\end{tabular}

1. E.coli 0157:H7

2. Shigella sonnei

3. Shigella flexeneri

4. Salmonella typhimurium

5. S.enteritidis

6. S.montevideo

7. Pseudomonas aeruginosa

8. Serratia liquefaciens

9. Citrobacter freundii

10. Enterobacter intermedius

11. Proteus mirabilis

12. Enterobacter cloaca

13. Yersinia pseudotuberculosi

14. Proteus penneri

15. Aeromonas

16. providencia stuartii

17. Proteus vulgaris

18. Erwinia cacticida

19. Serratia fonticola

20 Klebsiella pneumoniae subsp. Ozaenae

21 Coaggulase +ve $S$. aureus

22 Methicillin-resistant Coaggulase $3.7 \pm 1 \mathrm{~mm}$ -ve S.aureus strains using disc well diffusion method. (Fig.7), Table 3 shows the effect of $\mathrm{CuO}$ nanoparticles with chitosan at different concentration $1 \%, 2 \%, 3 \%, 5 \%$, chitosan with $\mathrm{CuO}$ nanoparticles showed significant antibacterial activity on Gram negative bacteria than Gram positive one. CuO nanoparticles with chitosan of concentration 3\%, 5\% strongly inhibited the growth of bacteria as the zone of inhibition recorded from $4.9 \mathrm{~mm}$ for Serratia fonticola to $8 \mathrm{~mm}$ for E.coli 0157 at concentration $3 \%$ for $\mathrm{CuO}$ nanoparticles with chitosan, while the zone of inhibition for the same concentration ranged from $3.9 \mathrm{~mm}$ to 4.1 for the Coaggulase +ve and methicillin-resistant Coaggulase -ve S. aureus Gram positive bacteria. The zone of inhibition for $\mathrm{CuO}$ nanoparticles with chitosan of concentration $5 \%$ recorded from $5.2 \mathrm{~mm}$ for Serratia fonticola to $8.5 \mathrm{~mm}$ for E.coli 0157 while the zone of inhibition for the same concentration ranged from 4.2 $\mathrm{mm}$ to 4.3 for the Coaggulase +ve and methicillinresistant Coaggulase -ve $S$. aureus gram positive bacteria. The zone of inhibition for $\mathrm{CuO}$ nanoparticles

Table. 2: Antibacterial activity of chitosan

\begin{tabular}{lll}
\hline No. & Bacteria & $\begin{array}{c}(\mathrm{mm}) \\
\text { (chitosan) }\end{array}$ \\
& & \\
\hline 1. & E.coli o157:H7 & $2.9 \pm 1 \mathrm{~mm}$ \\
2. & Shigella sonnei & $2 \pm 1 \mathrm{~mm}$ \\
3. & Shigella flexeneri & $2.4 \pm 1 \mathrm{~mm}$ \\
4. & Salmonella typhimurium & $2.7 \pm 1 \mathrm{~mm}$ \\
5. & S.enteritidis & $2.4 \pm 1 \mathrm{~mm}$ \\
6. & S.montevideo & $2.2 \pm 1 \mathrm{~mm}$ \\
7. & Pseudomonas aeruginosa & $2.8 \pm 1 \mathrm{~mm}$ \\
8. & Serratia liquefaciens & $2.5 \pm 1 \mathrm{~mm}$ \\
9. & Citrobacter freundii & $2.5 \pm 1 \mathrm{~mm}$ \\
10. & Enterobacter intermedius & $2.3 \pm 1 \mathrm{~mm}$ \\
11. & Proteus mirabilis & $2.3 \pm 1 \mathrm{~mm}$ \\
12. & Enterobacter cloaca & $2.1 \pm 1 \mathrm{~mm}$ \\
13. & Yersinia pseudotuberculosis & $2.8 \pm 1 \mathrm{~mm}$ \\
14. & Proteus penneri & $2.6 \pm 1 \mathrm{~mm}$ \\
15. & Aeromonas & $2.7 \pm 1 \mathrm{~mm}$ \\
16. & providencia stuartii & $2.3 \pm 1 \mathrm{~mm}$ \\
17. & Proteus vulgaris & $2.2 \pm 1 \mathrm{~mm}$ \\
18. & Erwinia cacticida & $2.3 \pm 1 \mathrm{~mm}$ \\
19. & Serratia fonticola & $2.2 \pm 1 \mathrm{~mm}$ \\
20 & Klebsiella pneumoniae & $2.5 \pm 1 \mathrm{~mm}$ \\
& subsp. Ozaenae & \\
21 & Coaggulase +ve S. aureus & $3.6 \pm 1 \mathrm{~mm}$ \\
22 & methicillin-resistant Coaggulase & $3.9 \pm 1 \mathrm{~mm}$ \\
& -ve S. aureus & \\
\hline & & \\
\hline
\end{tabular}


with chitosan at concentration $1 \%$ vary from 4.2 $\mathrm{mm}$ to $6.6 \mathrm{~mm}$ on Gram negative bacteria, $3.3 \mathrm{~mm}$ to $3.8 \mathrm{~mm}$ on Gram positive bacteria, at the same time the zone of inhibition for $\mathrm{CuO}$ nanoparticles with chitosan at concentration $2 \%$ ranged from 4.5 $\mathrm{mm}$ to $7 \mathrm{~mm}$ on Gram negative bacteria, $3.6 \mathrm{~mm}$ to $3.9 \mathrm{~mm}$ on Gram positive bacteria.
Scanning electron microscope for detection of morphological changes in bacteria by copper oxidnanoparticle

As seen in Fig.8 SEM analysis showed distribution an great changes in the cell morphology of E.coli O157:H7 (A,B), methicillin-resistant Coaggulase -ve $S$. aureus $(C, D)$ bacteria treated with Copper oxide nanoparticles.

Table. 3: Antibacterial activity of chitosan with CuO nanoparticles ( $\mathrm{mm}$.)

\begin{tabular}{|c|c|c|c|c|c|}
\hline \multirow[t]{2}{*}{ No. } & \multirow[t]{2}{*}{ Bacteria } & \multicolumn{4}{|c|}{ Chitosan with $\mathrm{CuO}$ nanoparticles (mm.) } \\
\hline & & $1 \%$ & $2 \%$ & $3 \%$ & $5 \%$ \\
\hline 1. & E.coli o157:H7 & $6.6 \pm 1 \mathrm{~mm}$ & $7 \pm 1 \mathrm{~mm}$ & $8 \pm 1 \mathrm{~mm}$ & $8.5 \pm 1 \mathrm{~mm}$ \\
\hline 2. & Shigella sonnei & $6.2 \pm 1 \mathrm{~mm}$ & $6.5 \pm 1 \mathrm{~mm}$ & $7 \pm 1 \mathrm{~mm}$ & $8 \pm 1 \mathrm{~mm}$ \\
\hline 3. & Shigella flexeneri & $5.3 \pm 1 \mathrm{~mm}$ & $6 \pm 1 \mathrm{~mm}$ & $6.5 \pm 1 \mathrm{~mm}$ & $7 \pm 1 \mathrm{~mm}$ \\
\hline 4. & Salmonella typhimurium & $6.4 \pm 1 \mathrm{~mm}$ & $7 \pm 1 \mathrm{~mm}$ & $7.5 \pm 1 \mathrm{~mm}$ & $8 \pm 1 \mathrm{~mm}$ \\
\hline 5. & s.enteritidis & $4 \pm 1 \mathrm{~mm}$ & $4.3 \pm 1 \mathrm{~mm}$ & $4.8 \pm 1 \mathrm{~mm}$ & $5 \pm 1 \mathrm{~mm}$ \\
\hline 6. & s.montevideo & $5 \pm 1 \mathrm{~mm}$ & $5.5 \pm 1 \mathrm{~mm}$ & $5.7 \pm 1 \mathrm{~mm}$ & $5.9 \pm 1 \mathrm{~mm}$ \\
\hline 7. & Pseudomonas aeruginosa & $6.5 \pm 1 \mathrm{~mm}$ & $6.8 \pm 1 \mathrm{~mm}$ & $7 \pm 1 \mathrm{~mm}$ & $7.3 \pm 1 \mathrm{~mm}$ \\
\hline 8. & Serratia liquefaciens & $4.2 \pm 1 \mathrm{~mm}$ & $4.5 \pm 1 \mathrm{~mm}$ & $4.9 \pm 1 \mathrm{~mm}$ & $5.1 \pm 1 \mathrm{~mm}$ \\
\hline 9. & Citrobacter freundii & $5.1 \pm 1 \mathrm{~mm}$ & $5.6 \pm 1 \mathrm{~mm}$ & $5.9 \pm 1 \mathrm{~mm}$ & $6.2 \pm 1 \mathrm{~mm}$ \\
\hline 10. & Enterobacter intermedius & $4.8 \pm 1 \mathrm{~mm}$ & $5 \pm 1 \mathrm{~mm}$ & $5.3 \pm 1 \mathrm{~mm}$ & $5.8 \pm 1 \mathrm{~mm}$ \\
\hline 11. & Proteus mirabilis & $5.1 \pm 1 \mathrm{~mm}$ & $5.3 \pm 1 \mathrm{~mm}$ & $5.8 \pm 1 \mathrm{~mm}$ & $6 \pm 1 \mathrm{~mm}$ \\
\hline 12. & Enterobacter cloaca & $4.7 \pm 1 \mathrm{~mm}$ & $4.9 \pm 1 \mathrm{~mm}$ & $5.3 \pm 1 \mathrm{~mm}$ & $5.8 \pm 1 \mathrm{~mm}$ \\
\hline 13. & Yersinia pseudotuberculosis & $5 \pm 1 \mathrm{~mm}$ & $5.5 \pm 1 \mathrm{~mm}$ & $6 \pm 1 \mathrm{~mm}$ & $6.3 \pm 1 \mathrm{~mm}$ \\
\hline 14. & Proteus penneri & $4.6 \pm 1 \mathrm{~mm}$ & $4.9 \pm 1 \mathrm{~mm}$ & $5 \pm 1 \mathrm{~mm}$ & $5.3 \pm 1 \mathrm{~mm}$ \\
\hline 15. & Aeromonas & $6 \pm 1 \mathrm{~mm}$ & $6.4 \pm 1 \mathrm{~mm}$ & $6.7 \pm 1 \mathrm{~mm}$ & $6.9 \pm 1 \mathrm{~mm}$ \\
\hline 16. & providencia stuartii & $5.8 \pm 1 \mathrm{~mm}$ & $6 \pm 1 \mathrm{~mm}$ & $6.4 \pm 1 \mathrm{~mm}$ & $6.8 \pm 1 \mathrm{~mm}$ \\
\hline 17. & Proteus vulgaris & $6 \pm 1 \mathrm{~mm}$ & $6.3 \pm 1 \mathrm{~mm}$ & $6.5 \pm 1 \mathrm{~mm}$ & $6.9 \pm 1 \mathrm{~mm}$ \\
\hline 18. & Erwinia cacticida & $4.9 \pm 1 \mathrm{~mm}$ & $5 \pm 1 \mathrm{~mm}$ & $5.4 \pm 1 \mathrm{~mm}$ & $5.8 \pm 1 \mathrm{~mm}$ \\
\hline 19. & Serratia fonticola & $4.4 \pm 1 \mathrm{~mm}$ & $4.7 \pm 1 \mathrm{~mm}$ & $4.9 \pm 1 \mathrm{~mm}$ & $5.2 \pm 1 \mathrm{~mm}$ \\
\hline 20 & $\begin{array}{l}\text { Klebsiella pneumoniae } \\
\text { subsp. Ozaenae }\end{array}$ & $6.3 \pm 1 \mathrm{~mm}$ & $6.6 \pm 1 \mathrm{~mm}$ & $6.9 \pm 1 \mathrm{~mm}$ & $7.1 \pm 1 \mathrm{~mm}$ \\
\hline 21 & Coaggulase +ve S. aureus & $3.3 \pm 1 \mathrm{~mm}$ & $3.6 \pm 1 \mathrm{~mm}$ & $3.9 \pm 1 \mathrm{~mm}$ & $4.2 \pm 1 \mathrm{~mm}$ \\
\hline 22 & $\begin{array}{l}\text { Methicillin-resistant Coaggulase } \\
\text {-ve S. aureus }\end{array}$ & $3.8 \pm 1 \mathrm{~mm}$ & $3.9 \pm 1 \mathrm{~mm}$ & $4.1 \pm 1 \mathrm{~mm}$ & $4.3 \pm 1 \mathrm{~mm}$ \\
\hline
\end{tabular}

\section{DISCUSSION}

Now day the field of nanotechnology and its based product of nanoparticles applications are increased due to its many great biological effectiveness. In the present investigation, the green synthesis method is used to synthesize the Copper oxide nanoparticles using aqueous leaf extract of Ficus carica which is eco-friendly cost effective approach when compared to other reported several method used for preparing copper oxide nanoparticles ${ }^{33}$, as it has been reported that the amino acids, enzymes and abundance of carboxylate and hydroxyl groups present in plants might play an important role at the formation of copper hydroxide which hydrolyzed later into nanocrystalline $\mathrm{CuO}^{34}$. It is well known that copper oxide nanoparticles optical properties are strongly dependent on their size, shape and the structure of the nanoparticles that can be studied by using the UV/Vis spectra. The typical UV/Vis spectra of the Copper oxide nanoparticles synthesized are shown in Fig.2. The nanoparticles exhibited one characteristic absorbance peak at $437 \mathrm{~nm}$, however 
the electromagnetic radiation formed the surface plasmon absorption in copper oxide nanoparticles through excitation of collective oscillation free electron conduction band, this type of resonance occur when the wavelength of the incident light far exceeds the particle diameter ${ }^{35}$. Surface plasmon absorption band with a maximum at $437 \mathrm{~nm}$ reported the formation of copper oxide nanoparticles ${ }^{36}$. Fig. 3 and 4 show the typical SEM and TEM images of the CuO-NPs, respectively that showed the particles are nearly spherical in nature with rough agglomeration of average diameter around 51-62 $\mathrm{nm}$. The highly agglomeration of the nanoparticles synthesis by this method may be explained by the increase in the catalytic activity of the surface nanoparticles ${ }^{37}$, that can illustrate the higher antibacterial activity of the CuO-NPs. The XRD pattern in Fig. 5 revealed the orientation and crystalline nature of copper oxide nanoparticles that agreement with the International Center of Diffraction Data card (JCPDS-80-1916) to confirm the formation of a crystalline monoclinic structure ${ }^{38}$ also sharp peaks structures in XRD patterns and crystallite size less than $100 \mathrm{~nm}$ indicated the nanocrystalline nature of CuO-NPs as the highest peak observed in XRD pattern represented crystallite size of 14 $\mathrm{nm}$ using Debye-Scherrer equation as described. FT-IR analysis in Fig. 6 is used to determine an approximate ides possible biomolecules that are responsible for stabilized and capping the formed CuO-NPs with Ficus carica leaf extract. The FTIR analysis of CuONPs Fig. 6(A) investigated that they might surround by the any of these organic molecules such as alkaloids, terpenoids, fatty acids and polyphenols which have reducing, capping capacity and have a big role in the reduction of copper ions to copper nanoparticles that results agreement with Kalainila et al., who reported the same type of results ${ }^{39}$. Chitosan-CuO composite FTIR spectra as seen in Fig. (6)C displayed the characteristic bands of both Chitosan and $\mathrm{CuO}$. The band at 400 $\mathrm{cm}^{-1}$ was ascribed to the stretching mode of $\mathrm{Cu}-\mathrm{O}^{40}$. When compared to the pure chitosan FTIR spectra in Fig. (6)B ,the bands represented the amide, amino and hydroxyl groups were shifted. The shift of FTIR bands confirmed that the $\mathrm{CuO}$ nanoparticle was mixed with polymer. The antibacterial activity of the $\mathrm{CuO}$ nanoparticles, chitosan and $\mathrm{CuO}$ nanoparticles with chitosan composite at different concentration were evaluated against two Gram positive and twenty Gram negative bacterial strains using disc well diffusion method. CuO nanoparticles showed significant antibacterial activity against all bacterial strains as seen in Table 1 and agree with previous results of Hassan et al., and Vinod et al., who demonstrated that Copper oxide ( $\mathrm{CuO}$ ) nanoparticles synthesized from leaf extracts acts as an effective antimicrobial agent against game positive infectious organisms such as Staphylococcus aureus, Bacillus subtilis and grame negative organisms as E. coli, Vibrio cholerae and Pseudomonas aeruginosa ${ }^{34,41}$. The bactericidal effects observed in this study as a result of $\mathrm{Cu} 2+$ ions released in solution by the NPs that binding to the bacterial cell surface of the negative charge, changing its permeability that leading to come out of material inside the bacterial cells causes its death. The mechanism investigated by Azam et al and Stochs et al., reported that the copper ion causes disorders of the cellular proteins, lipids and helical structure of DNA molecules through crosslinking between and within the nucleic acid strands and destroy the biochemical process, also the reaction of copper with sulfhydryl (-S-H) groups and oxygen on the cell wall forms R-S-S-R bonds that blocks respiration centers of the cell and cause its damage ${ }^{42,43}$. The diameter of inhibition zone indicated susceptibility of microbes, the susceptible strains to CuO-NPs showed larger zone of inhibition, while resistant strains showed smaller zone of inhibition. According to zone of inhibition the CuO-NPs as seen in Table 1 exhibited more inhibitory activity towards gram negative than gram positive bacteria as seen in (Fig.7, Table 1 ) because there is a difference in structure of the bacterial cell wall as gram negative cell wall consists of single peptidoglycan layer while gram positive cell wall have several peptidoglycan layers $^{12}$, in contrast to J. Emima Jeronsia et al., who observed that the Grampositive bacterial strains have higher sensitivity to CuO-NPs than Gramnegative ${ }^{44}$. In our research we demonstrated the antibacterial activity of chitosan towards Gram positive and gram-negative bacteria as recorded in Table. 2 and agreed with many investigation recorded that chitosan shows antibacterial activity towards both gram-negative and Gram positive bacteria due to the nature of chitosan surface of as polycation of high charge density which tightly attached and absorbed onto the surface of bacterial membrane to disrupt the cell membrane, thus kill bacterial cells $s^{27,28,45,46}$. Also Chitosan can form various chemical bonds with 
metal particles and prevents agglomeration, thus increasing the stability of the NPs ${ }^{26}$.

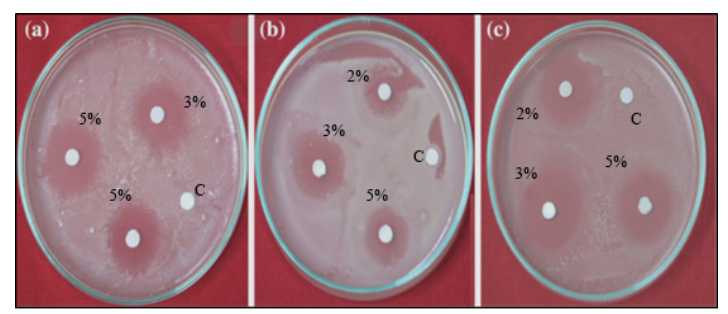

Fig.7. Antibacterial activity of Chitosan with $\mathrm{CuO}$ nanoparticles at concentration $2,3,5 \%$, negative control () : Zone of inhibition against (a) Salmonella typhimurium, (b) methicillin-resistant Coaggulase -ve S. aureus and (c) E.coli 0157 bacteria.

The chitosan medium increase the efficiency of the antimicrobial activity of copper oxide nanoparticles against Gram negative, Gram positive organisms that indicated by the zones of inhibition as shown in Table.3, it was observed that zones of inhibition against Gram negative and gram positive bacteria for $\mathrm{CuO}$ nanoparticles with Chitosan at concentration $1 \%$, $2 \%, 3 \%$, and $5 \%$ respectively was higher than zones of inhibition of $\mathrm{CuO}$ nanoparticles or chitosan alone, that agreement with study demonstrated that copper oxide nanoparticles embedded within polypropylene exhibiting stronger antimicrobial activity than metal copper nanoparticles ${ }^{47}$ as coatings based on copper / polymer which called ex situ, the matrix is act as dispersion medium and the polymer incorporated into the synthesized cupper nanoparticles to develop antimicrobial activity ${ }^{48,49}$. The mechanisms for the antimicrobial behavior of metal/polymer nanocomposites based on thermoplastic matrices explained by the adsorption of bacteria on the polymer surface that cause water to be diffused through the polymer matrix leading to corrosion processes and release of metal ions and water that dissolved in oxygen to the metal/polymer nanocomposite surface causing destroy bacterial membrane ${ }^{25,50,47,51,30}$. The morphological changes and disruption of the bacterial cell membrane of copper oxide nanoparticlen treated bacteria was supported by SEM analysis as seen in Fig.8, the tested bacteria strains coli O157:H7, and methicillinresistant Coaggulase -ve $S$. aureus, as it find the way into the bacterial cells causing great lipid bilayer and membrane protein damage as reported in previous studies $9,10,11,24,52,53,54$.

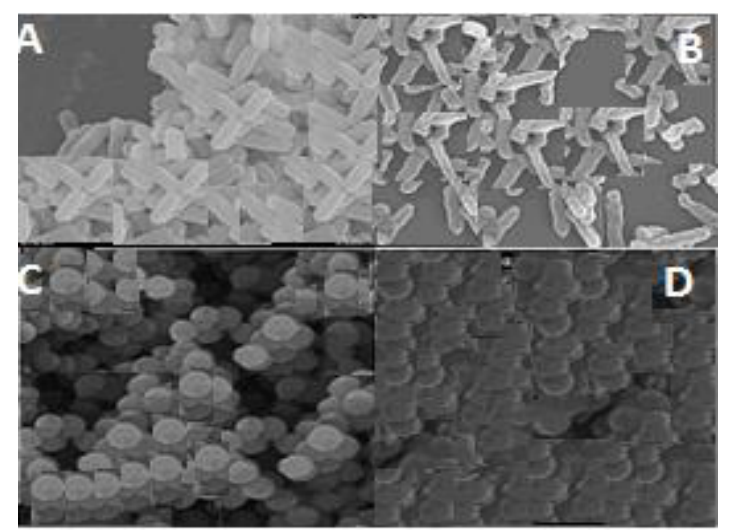

Fig. 8. Scanning electron micrographs of E.coli 0157:H7 (A) and methicillin-resistant Coaggulase-ve S. aureus (C) . SEM images were taken from the bacterial cells coli 0157:H7 (B), and methicillin-resistant Coaggulase -ve S. aureus (D) treated with $2 \mathrm{mg} / \mathrm{ml}$ CuO nanoparticles for $\mathbf{8} \mathrm{h}$. The control cells were incubated under the same conditions without nanoparticles

\section{CONCLUSION}

we have demonstrated a simple biological approach to fabricate highly stable copperoxide nanoparticles embedded in a natural polymer by green method from Ficus carica plant extract .The antibacterial properties of copper oxide nanoparticle, chitosan and Copper oxide chitosan nanoparticle composite were investigated against two Grampositive and twenty Gram-negative bacteria. The results investigated that Addition of polymers to metal-based particles enhanced to great extent antimicrobial properties. Although there are many research investigated copper oxide nanoparticle embedded into different polymer matrices forming composite, further research is very important to support the development of bioactive polymeric materials can be easily fabricated into fiber and film for producing promise biocide materials for further extension of applications can be used as in bed lining, cotton ban-dages, wound dressing as well as for medical in hospital equipment or in prostheses and food applications.

\section{REFERENCES}

1. Ren, $\mathrm{G} ; \mathrm{Hu}, \mathrm{D} ;$ Cheng, $\mathrm{C}$; .Vargas-Reus, M; Reip,P ; Allaker ,RP, International Journal of Antimicrobial Agents. 2009, 33, 587-590.
2. Bai, C. Liu, M. Nano Today. 2012, 7, 258-281.

3. Thanh, N. T. K. ; Green, L. A. W. Nano Today. 2010, 5, 213-230 
4. Brege, J. J.; Hamilton, C. E; Crouse, C. A ; Barron, A. R. Nano Lett. 2009, 9, 22392242.

5. Comfort, K. K ; Maurer, E. I ; Braydich-Stolle, L. K ; Hussain, S. M. ACS Nano. 2011, 5, 10000-10008.

6. Yang,S ; Wang, C; Chen,L; Chen,S ;. Chem. Phys., 2010, 120, 296-301.

7. Debbichi,L; Marco de Lucas,M.C ; Pierson, J.F; Krüger, P ; Phys, J .Chem. C . 2012, 116, 10232-10237.

8. Baek , Y.-W ; An, Y.-J "Science of the Total Environment. 2011 , 409 (8), 1603-1608.

9. Bondarenko, O; Ivask, A; Käkinen, A; Kahru,A. Environmental Pollution .2012, 169 ,81-89.

10. Jadhav,S; Gaikwad,S; Nimse, M; Rajbhoj, A. Journal of Cluster Science.2011, 22 , 121-129.

11. Studer,A.M ; Limbach,L.K; Van Duc, L. Toxicology Letters . 2010 , 197(3) 169174

12. Li Q; Mahendra S; Lyon D.Y; Brunet ,L; Liga, M. Water Research . 2008 , 42: 4591-4602.

13. Ravikumar,B. S; Nagabhushana, H; Sunitha,D.V ; Sharma,S.C ; Nagabhushana, B.M ; Shivakumara,C ; Alloys. J . Compd. 2014, 585 , 561-571.

14. Sastry,M; Shankar,S.S; Rai,A; Ahmad ,A. J. Colloid Inter face Sci . 2004, 275, 496-502.

15. Huang,J ; Li, Q; D; Sun, Y;Lu, Y; Su, X. Yang, H. Wang, Y.Wang, W. Shao, N. He, J. Hong, C. Chen, Nanotechnology. 2007,18, 105104-105115

16. Ankamwar,B; Chinmay,D; Absar,A; Murali, S. Nanosci.J. Nanotechnol. 2005,10, 16651671.

17. Ankamwar,B ; Chaudhary,M ; Murali,S. NanoMetal Chem. 2005, 135 ,9-26.

18. Shankar,S.S; Rai, A; Ankamwar,B; Ahmad,A; M. Sastry,M. Nat.Mater. 2004 , 3, 482-488.

19. Gardea-Torresdey, J.L ; Parsons,J.G; Gornez,E; J. Videa,J; Troiani,H.E ; Santiagol, P. Nano Lett. 2002, 2 ,397-401.

20. Gardea-Torresdey, J.L ; Parsons,J.G; Gornez,E; J. Videa,J; Troiani,H.E ; Yacaman, M Langmuir .2003 , 19,1357-1361.

21. De Azeredo, H.M.C. Nanocomposites for food packaging applications. Food Res. Int. 2009, 42, 1240-1253.
22. Paul, D.R.; Robeson, L.M. Polymer nanotechnology: Nanocomposites. Polymer. 2008, 49, 3187-3204.

23. Lemire, J.A.; Harrison, J.J.; Turner, R.J. Nat. Rev. Microbiol. 2013, 11, 371-384.

24. Gunawan, C.; Teoh, W.Y.; Marquis, C.P.; Amal, R.. ACS Nano. 2011, 5, 7214-7225.

25. Muñoz-Bonilla, A; Fernández-García, M.. Prog. Polym. Sci. 2012, 37, 281-339.

26. Muzzarelli, R.A. . Carbohydr Polym. 2011, 84, 54-63.

27. Avadi ,M ;Sadeghi, A ;Tahzibi ,A; Bayati, K; Pouladzadeh, M ;Zohuriaan-Mehr, M; RafieeTehrani, M. 2004, 40, 1355-1361.

28. Abou-Zeid, N; Waly, A; Kandile, N; Rushdy, A; El-Sheikh, M; Ibrahim, H.. Carbohydrate Polymers, 2011, 84 (1), 223-230.

29. Lu, Y; Cheng, D; Lu, S; Huang, F; Li, G.. Textile Research Journal, 2014, 84 , 2115-2124.

30. Cioffi, N.; Torsi, L.; Ditarantano, N.; Tantalillo, G.; Ghibelli, L.; Sabbatini, L.; Bleve-Zacheo, T.; D’Alessio, M.; Zambonin, P.G.; Traversa, E. Chem. Mater. 2005, 17, 5255-5262.

31. Pinto, R.J.; Daina, S.; Sadocco, P.; Pascoal Neto, C.; Trindade, T. Biomed. Res. Int. 2013, doi: 10. 1155/2013/280512.

32. Xie, Y; He, Y; Irwin, P.L; Jin, T; Shi, X. Appl Environ Microbiol. 2011, 77, 2325-2331. doi: 10.1128/AEM.02149-10.

33. Sankar, R; Manikandan, P; Malarizhi, V; Fathima, T; Shivashangari, K.S; Ravikumar, V. Spectrochimica Acta A: Molecular and Biomolecular Spectroscopy. 2014, 121, 746750.

34. Vinod, Vellora.; Thekkae, Padil ; Miroslav, Cernik.. Int. J. Nanomedicine. 2013, 8, 889 - 898

35. Raja ,Naikaa ; Lingaraju,K ; Manjunath,K; Danith Kumar, G; Nagarajuc, G; Suresh, $\mathrm{H}$; Nagabhushanaea, C .Journal of Taibah University for Science 2015, 9, 7-12.

36. Dhaneswar, D ; Nathb,B.C ; P. Phukonc, P; Doluia,S.K; ColloidsSurf.J ; B: Biointerfaces. 2013, 101, 430-433.

37. Awwad, A.M; Albiss, B.A;Salem, N.M. SMU Medical Journal 2015, 2, 1.

38. The XRD patterns were indexed with reference to the crystal structures from the ASTM charts: $\mathrm{Cu}$ (chart card number 03-1005), $\mathrm{CuO}$ (chart card number 44-0706), $\mathrm{Cu}_{2} \mathrm{O}$ (chart card number 05-0667 and 03-0898) and $\mathrm{Cu}_{4} \mathrm{O}_{3}$ (chart card number 33-0480). 
39. Kalainila, P; Subha, V; Ernest, S; ravindran, R.S. Asian J Pharm Clin Res. 2014, 7, 3943.

40. Rahnama, A; Gharagozlou, M. .Optical and Quantum Electronics. 2012 , 44, 313-322

41. Hassan, M.S; Amna, T; Yang, O.B; Newehy, M.H. E; Al-Deyab, S.S; Khil, M.S. Colloids Surf B:Biointerfaces. 2012, 97, $201-206$.

42. Azam, A; Ahmed, A.S; Oves, M; Khan, M.S; Habib, S.S; Memic, A. Int J Nanomedicine. 2012, 7, 60039.

43. Stohs, S.J; Bagchi ,D. Free Radic Biol Med . 1995, 18, 32136.

44. Emima Jeronsia, J ; Vidhya Raj, D.J ; Allwin , L; Joseph, K; Rubini,1 ; Jerome Das,S . J Med Sci .2016, 36,145151

45. Lahmer. R.A; Williams, A.P; Townsend, S; Baker, S; Jones, D.L. Food Control. 2012, 26, 206-211

46. Lahmer. R.A; Williams, A.P; Townsend, S; Baker, S; Jones, D.L. American Journal of Food, Nutrition and Health. 2016, 1, 7-12
47. Delgado, K.; Quijada, R.; Palma, R.; Palza, H. Lett. Appl. Microbiol. 2011, 53, 50-54.

48. Zhang, W.; Zhang, Y.H.; Ji, J.H.; Zhao, J.; Yan, Q.; Chu, P.K. Polymer 2006, 47, 74417445.

49. Cometa, S.; latta, R.; Ricci, M.A.; Ferretti, C.; de Giglio, E. J. Bioact. Compat. Polym. 2013, 28, 508-522.

50. Palza, H.; Gutiérrez, S.; Delgado, K.; Salazar, O.; Fuenzalida, V.; Avila, J.; Figueroa, G.; Quijada, R .Macromol. Rapid Commun.2010, 31, 563-569.

51. Vimala, K.; Sivudu, K.S.; Mohan, Y.M.; Sreedhar, B.; Raju, K.M. Carbohydr. Polym. 2009, 75, 463-471.

52. Matai, I. Colloid. Surface B. 2014, 115, 359-367.

53. Newcomb, C. J. Nat Commun. 2014, 5, 1024-1031

54. Lu, Z.X; Zhou, L; Zhang, Z.L; Shi, W.L; Xie, Z.X; Xie, H.Y; Pang, D.W; Shen, P. Langmuir. 2003, 19, 8765-8768. 